\title{
Parents' Body Shape Profile and Overweight Among Students at Singkawang Adventist School
}

\author{
Sultan Fredyansyah Bagaskara Djula ${ }^{1}$, Sapti H. Widyarti Djula ${ }^{2}$ \\ ${ }^{1}$ Student, Universitas Advent Indonesia \\ ${ }^{2}$ Teacher, Universitas Advent Indonesia \\ sultandjula11@gmail.com
}

\begin{abstract}
When both parents are obesity, thus the children are $80 \%$ potentially become overweight or obesity. If one of the parent is overweight or obesity, thus the children are $40 \%$ potentially to become overweight or obesity. The purpose of the study is to analyze is there any significant relationship between parents' body shape with overweight among students at Singkawang Adventist School. The method of the study is descriptive with quantitative method and the cross sectional design. Sampling technique is total sampling among the overweight students. Number of respondens are 35 persons which have been measure body height, body weight and determined Body Mass Index (BMI). Data processing using SPSS Program. The results of the study show that the status of overweight students is obesity and parents' body shape are overweight (there is no significant relationship between obesity in adolescents with the body shape of the father with a significance of $(0.086)$ with a $\rho$ value $>0.05$ as well as no significant relationship between obesity in adolescents with the body shape of their mothers, with a significance of $(0.411)$ with $\rho$ value $>0.005)$. There is no significant relationship between overweight students with parents' body shape. There is not enough evidence to refuse null hypothesis. Recommendation are given to Singkawang Adventist School Students in order to maintain a healthy lifestyle and give effort to reduce body weight. To the next researcher to do research with bigger sample size.
\end{abstract}

Keywords: Overweight, Obesity, Body Mass Index(BMI), Body Shape.

\section{INTRODUCTION}

Socially, adolescence is the most enjoyable period in an individual's life as this time in a teenagers life, the individual builds social interactions together with peers, friends and even starting a deeper relationship with others as well as having relations with the opposite sex. Adolescence according to the the world health organization (who; 2007) is a group of humans 
that range from the ages of 10 to 19 years. The ministry of health of the republic of indonesia (moh, 2009) classifies adolescents as human groups ranging from 12 to 25 years of age. Adolescence is a dynamic phase of growth and development in an individuals life. Growth and development in this phase accelerates in which there is a transition from the pre adolescent phase to the adult phase which is full of various and comprehensive responsibilities and developmental tasks. Growth and development in this period covers all aspects, including physical, mental, spiritual, and social aspects in a person's life. Optimal growth and development, is strongly influenced by the interaction between biopsychososiospiritual factors and the surrounding environment.

According to who, the age range for teenagers starts from the ages of 12 to 24 years. This limit is different from the limits according to the ministry of health of the republic of indonesia. Adolescent limits according to the indonesian ministry of health in 2010, range from the ages 10 to 19 years and are not married. According to the indonesian hunting law, a person is considered a teenager when he reaches the age of 16 to 18 and is married or has his own place of residence. This classification is very different from the limits of adolescents according to the indonesian ministry of health. Adolescent limits according to the indonesian marriage law of 1974 , classifies a person as a teenager if the person is 16 years old for women and 19 years old for men.

\section{LITERATURE REVIEW}

In accordance with of word origin of adolescents is "Adolescence" which means growing or growing into adults, adolescents will experience maturity. Maturity includes: physical, emotional, and social maturity. Emotional characteristics of a teen can include: anger, anxiety, fear, affection, curiosity, jealousy, etc. This emotional maturity is a reflection of a happy and displeased state of a person or a situation that is experienced. While the physical characteristics of a teenager are: maximum physical growth, especially height (Santrock, 2007). While Walgito (2004) describes the emotional maturity of adolescents which include: acceptance of the state of him/herself and the state of others as they are, setting his/her mind to respond to the stimulus received, the ability to control emotions properly, can be patient as an expression 
of tolerance to work well, and can be responsible for themselves. Physical maturity is one of the characteristics an adolescent possesses, which is a maximum growth of height that occurs swiftly. This happens because in adolescence, a person receives a significantly increased food intake than when as a child. As a result, adolescents receive excessive food intake and even obesity. According to Dewi (2007), the state of being overweight and obesity are excessive or abnormal fat accumulations that can affect one's health. Obesity is usually a chronic condition characterized by excess body fat. This usually occurs because of an increase in food intake into the body, while the output of fat burning is low. The output intended here is energy produced from low body metabolism, resulting in an imbalance between food intake and energy in the form of physical activity that is released, and stored in the form of fat (Roesli; 2014). Body Mass Index (BMI) is a simple index based on body weight and height that is commonly used to determine whether a person is classified as underweight, overweight or obese. BMI is obtained from body weight divided by height in meters squared. BMI is a value that does not depend on age and is the same for both sexes. This means that age does not affect the measurement of the BMI value, nor does gender affect the measurement of the BMI value. BMI may not correspond to the same degree of obesity in different populations, because some differ in body proportions. Health risks associated with a continuous increase in BMI and interpretation of gradations in BMI in terms of risk may differ in different populations.

\section{Factors of Obesity.}

According to Hayati (2009), there are 3 factors that cause obesity. These three factors are: food intake, physical energy expenditure and hormonal factors. Meanwhile, predisposing factors to obesity include: genetic factors and environmental factors.

\section{Genetic Factors.}

Pipes Research outlines that there are $60-70 \%$ of adolescents that are obese and have both parents overweight or one parent overweight. Parents who are overweight can be ensured that the cause of obesity to their children derives from them. If both parents are overweight, then $80 \%$ of those genetics are passed down to their children. If one parent is overweight, then the chance of their child experiencing obesity is $40 \%$. However, if both parents are not overweight, the chances of their children becoming overweight is $14 \%$. Thus, an increased risk of obesity may occur due to the influence of genes (the environment in the family). 


\section{Environmental Factors.}

Environmental factors can be classified into 2, namely: environmental factors within the family and environmental factors outside the family. Environmental factors in the family, can be influenced by: consumption of breast milk, breakfast habits, eating habits, and physical activities.

\section{Environmental Factors within the Family.}

From birth until one year of age a baby will recieve breast milk as a food source. Exclusive breastfeeding should be received by the baby from birth until the age of 6 months. This means, that a baby should only be given breast milk as a source of nutrition and fluids. A baby should not be given any food, including tea water or just plain water. Nutritional needs are sourced from breast milk.

It will be a health problem and pose a risk leading to obesity, if during the period of time the baby receieves exclusive breastfeeding but given additional food. According to Handayani (2007), breastfeeding can reduce the risk of obesity if given within a period of 12 to 24 months. According to Pareira (2008), adolescents who do not eat breakfast before going to school will have a tendancy to be overweight compared to adolescents who do eat breakfast. This can happen because teenagers who have breakfast can control their appetite better throughout the day. Teenagers can control their appetite in the afternoon and evening, so obesity can be avoided. According to Albiner (2008), that breakfast is an effect on the rhythm, patterns and eating cycles of a person, so eating should be done regularly on a daily basis. Eating habits, is the way individuals or groups determining food choices associated with: culture, physical activity, and psychological factors. Damayanti (2002) revealed in a study in Semarang, that people that eat more than 3 times will be at risk of being overweight 2.1 times compared to those who eat less or equal to 3 meals. Another thing included in the eating habit is the habit of snacking. Usually snacks are made from basic ingredients of flour and sugar. Children choose snacks they like without considering the amount of calories and protein contained in them. Another eating habit is if someone is accustomed to eating snacks between meals as we;;, when a person enjoys a snack usually while watching television. This habit is difficult to stop because the number of calories that enter slowly increases uncontrollably. Frequent watching 
is positively correlated with snacking behavior. The longer a person watches television, the greater the risk of being overweight.

\section{Environmental factors outside the family.}

Physical activity is all activities carried out using muscle energy. Physical activities can include: sports, daily habits, hobbies, and others. Physical accretion is a way to increase energy expenditure, so that energy reserves caused by the accumulation of food in the body will be burned to produce motion energy.

Someone who lacks physical activity will be at risk of being overweight. Pipes (1993), written by Hayati (2007), described that inactivity or lack of movement is the cause of obesity. Parents have a big role in providing motivation for children to do activities. By being an example to children, the children will enjoy every physical activity carried out, and will then become a habit that will be done every day.

\section{Body Shape Concept.}

Body shape is a complex phenomenon with detailed functions. While the general shape of the body is the formation of bone structure, and the distribution of muscle and fat. According to the contemporary English dictionary of Longman, body shape used especially when it is done in sports and diet. Skeletal structures grow and reach a point where humans can reach adulthood and end up old. Growth usually reaches its peak between the ages of 13 to 18 where epiphyseal plates in long bones close, making it impossible for further growth.

During adolescence, differences between male and female bodies occur related to the process of reproduction. Furthermore, muscle mass can change due to exercise. Fat distribution can also change due to hormonal fluctuations. Genes passed from parents to children also play a significant role in the development of body shape.

Various parts of the body can undergo changes in shape. According to Holden \& Constance (2018), changes in body shape include: facial changes, skeleton structure, distribution of fat, muscle and tissue, weight, and body posture. Facial changes result from testosterone in men, where facial development occurs at puberty. The face is formed by the protrusion of the temples starting from the brow bone, the strong jaw, the larger head size, the chin that hangs up to the shape of an enlarged and elongated nose. These facial changes occur more in men than women. 
But women have a quarter of the amount of Testosterone in men, so that a woman's face is generally the same as the face before puberty.

Skeleton structure in general does not change after maturity. Men generally get taller but body shape can be analyzed for further conclusions. In women, the pelvic bone widens as part of puberty. This widening occurs due to the presence of the hormone estrogen. This widening is intended to prepare for childbirth. Similarly, the sacrum bone becomes shorter and wider. This change brings a woman to have a pattern in walking, so the hips appear to swing. After puberty, the hips are usually wider than the shoulders. In men, shoulder widening usually occurs as part of puberty. Expansion of the thoracic cavity is caused by the effects of testosterone during puberty.

The shape of the body can be caused by the distribution of the mother's body, which is related to the level of existing sex hormones. The distribution of fat and muscle can change from time to time, whereas bone structure depends on eating habits, exercise and hormone levels. In women, estrogen can cause fat storage in women's buttocks, thighs and pelvis. However, after menopause, estrogen produced by the ovaries decreases, fat moves from the buttocks, hips and thighs to the waist. The following table presents the international classification of underweight, overweight and obesity based on the Body Mass Index (BMI).

Table 1. Scale According to the Who of Male Body Shape

\begin{tabular}{ccl}
\hline INTERVAL & CATEGORY & INTERPRETATION \\
$<18 \mathrm{~kg} / \mathrm{m}^{2}$ & 1 & Underweight \\
$18-25 \mathrm{~kg} / \mathrm{m}^{2}$ & 2 & Normal \\
$25-27 \mathrm{~kg} / \mathrm{m}^{2}$ & 3 & Overweight \\
$>27 \mathrm{~kg} / \mathrm{m}^{2}$ & 4 & Obesity \\
\hline
\end{tabular}

Table 2. Scale According to the Who of Female Body Shape

\begin{tabular}{lcl}
\hline INTERVAL & CATEGORY & INTERPRETATION \\
$<17 \mathrm{~kg} / \mathrm{m}^{2}$ & 1 & Underweight \\
$17-23 \mathrm{~kg} / \mathrm{m}^{2}$ & 2 & Normal \\
$23-27 \mathrm{~kg} / \mathrm{m}^{2}$ & 3 & Overweight \\
$>27 \mathrm{~kg} / \mathrm{m}^{2}$ & 4 & Obesity \\
\hline
\end{tabular}




\section{METHODS}

This research uses a descriptive research method, with a Cross Sectional design by involving teenagers in junior high school and high school students of Singkawang Adventist Academy who are willing to participate to be used as a population. The sampling technique used is total sampling. While the sample is all students who are overweight and obese (overweight) according to WHO (2014). To determine the variable of obesity, measurements of height and weight as well as age and sex are measured for the members of the population. After obtaining students in the obesity category, students are notified and asked if they are willing to participate in the research. After stating their willingness to sign an informed consent, an explanation was given regarding the research process. Furthermore students who are selected and willing to participate are collected in one classroom for data collection. This research is based on the hypothesis that:

H0: There is no significant relationship between students 'obesity and their parents' body shape profile.

Ha: There is a significant relationship between student obesity and parental body shape profile. The population in this study were all students at Singkawang Adventist School, amounting to 93 people who participated in learning activities at the time the study was conducted. While the sample is a portion of the population, i.e. a portion of students who took measurements of height and weight as well as a grouping of students who are experiencing the state of being overweight and those who are obese.

Sample Criteria.

The criteria for selecting a sample is a requirement used to determine the sample to be selected in the study. Criteria include:

1. Subjects are students who are teenagers (12 to 20 years old), both male and female, who attend the Singkawang Adventist School, including: middle and high school students.

2. The object of research is: student obesity and parents' body shape.

3. All samples used in the study are those who can read and write, and are willing to participate in research indicated by the willingness to sign an Informed Concent. 


\section{RESULTS}

Analysis of the Demographic Distribution of Respondents

The number of respondents who participated in this study amounted to 35 people, who will be analyzed data based on age, gender and weight.

1. Age of Respondents. Age of respondents ranged from 12 to 19 years old, with the distribution of: the one with the highest frequency were those that were 16 years with a percentage of $28.6 \%$, while the ones with the lowest frequency were those who's age were 18 years old with a percentage of $2.9 \%$. While the average age of respondents is 15.4 years.

2. Gender. The sex of the respondents consisted of men and women, with a distribution of respondents who were 21 (men) (60\%) and the least respondents of 14 (women) $(40 \%)$.

3. Weight. The respondent's weight is spread from $52.40 \mathrm{~kg}$ to $122.8 \mathrm{~kg}$, with an average respondent's body weight of $75.15 \mathrm{~kg}$.

4. Height. The respondent's height is ranged from 1.43 meters to 1.80 meters, with an average height of the respondent's body being 1.64 meters.

Formulation of the first problem: "What is the obesity level of adolescents at Singkawang Adventist School?"

The question is then answered by first determining the Body Mass Index (BMI).

\section{Reporting Research Result}

Table 3. Age of Respondents

\begin{tabular}{|r|r|r|r|r|}
\hline & Frequency & Percent & Valid Percent & $\begin{array}{c}\text { Cumulative } \\
\text { Percent }\end{array}$ \\
\hline 12.00 & 2 & 5.7 & 5.7 & 5.7 \\
13.00 & 7 & 20.0 & 20.0 & 25.7 \\
14.00 & 3 & 8.6 & 8.6 & 34.3 \\
15.00 & 2 & 5.7 & 5.7 & 40.0 \\
Valid & 10.00 & 28.6 & 28.6 & 68.6 \\
17.00 & 8 & 22.9 & 22.9 & 91.4 \\
18.00 & 1 & 2.9 & 2.9 & 94.3 \\
19.00 & 2 & 5.7 & 5.7 & 100.0 \\
Total & 35 & 100.0 & 100.0 & \\
\hline
\end{tabular}


Descriptive Statistics

\begin{tabular}{|l|r|r|r|r|r|}
\hline & \multicolumn{1}{|c|}{$\mathrm{N}$} & Minimum & Maximum & Mean & Std. Deviation \\
\hline Age & 35 & 12.00 & 19.00 & 15.4000 & 1.92812 \\
Valid N (listwise) & 35 & & & & \\
\hline
\end{tabular}

Table 4. Gender

\begin{tabular}{|ll|r|r|r|r|}
\hline & Frequency & Percent & Valid Percent & $\begin{array}{c}\text { Cumulative } \\
\text { Percent }\end{array}$ \\
\hline \multirow{2}{*}{ Valid } & Female & 14 & 40.0 & 40.0 & 40.0 \\
& Male & 21 & 60.0 & 60.0 & 100.0 \\
& Total & 35 & 100.0 & 100.0 & \\
\hline
\end{tabular}

Descriptive Statistics

\begin{tabular}{|c|c|c|c|c|c|}
\hline & $\mathrm{N}$ & Minimum & Maximum & Mean & Std. Deviation \\
\hline $\begin{array}{l}\text { Weight } \\
\text { Valid N (listwise) }\end{array}$ & $\begin{array}{l}35 \\
35\end{array}$ & 52.40 & 122.80 & 75.1571 & 13.7270 \\
\hline
\end{tabular}

Table 5. Weight

\begin{tabular}{|c|r|r|r|r|}
\hline & Frequency & Percent & Valid Percent & \multicolumn{2}{|c|}{$\begin{array}{c}\text { Cumulative } \\
\text { Percent }\end{array}$} \\
\hline 52.40 & 1 & 2.9 & 2.9 & 2.9 \\
57.70 & 1 & 2.9 & 2.9 & 5.7 \\
58.60 & 1 & 2.9 & 2.9 & 8.6 \\
59.30 & 1 & 2.9 & 2.9 & 11.4 \\
65.00 & 1 & 2.9 & 2.9 & 14.3 \\
65.80 & 1 & 2.9 & 2.9 & 17.1 \\
66.00 & 2 & 5.7 & 5.7 & 22.9 \\
66.50 & 1 & 2.9 & 2.9 & 25.7 \\
66.90 & 2 & 5.7 & 5.7 & 31.4 \\
68.50 & 1 & 2.9 & 2.9 & 34.3 \\
68.60 & 1 & 2.9 & 2.9 & 37.1 \\
69.00 & 2 & 5.7 & 5.7 & 42.9 \\
70.50 & 1 & 2.9 & 2.9 & 45.7 \\
71.80 & 1 & 2.9 & 2.9 & 48.6 \\
72.90 & 1 & 2.9 & 2.9 & 51.4 \\
73.80 & 1 & 2.9 & 2.9 & 54.3 \\
74.00 & 1 & 2.9 & 2.9 & 57.1 \\
& & & & \\
\hline
\end{tabular}




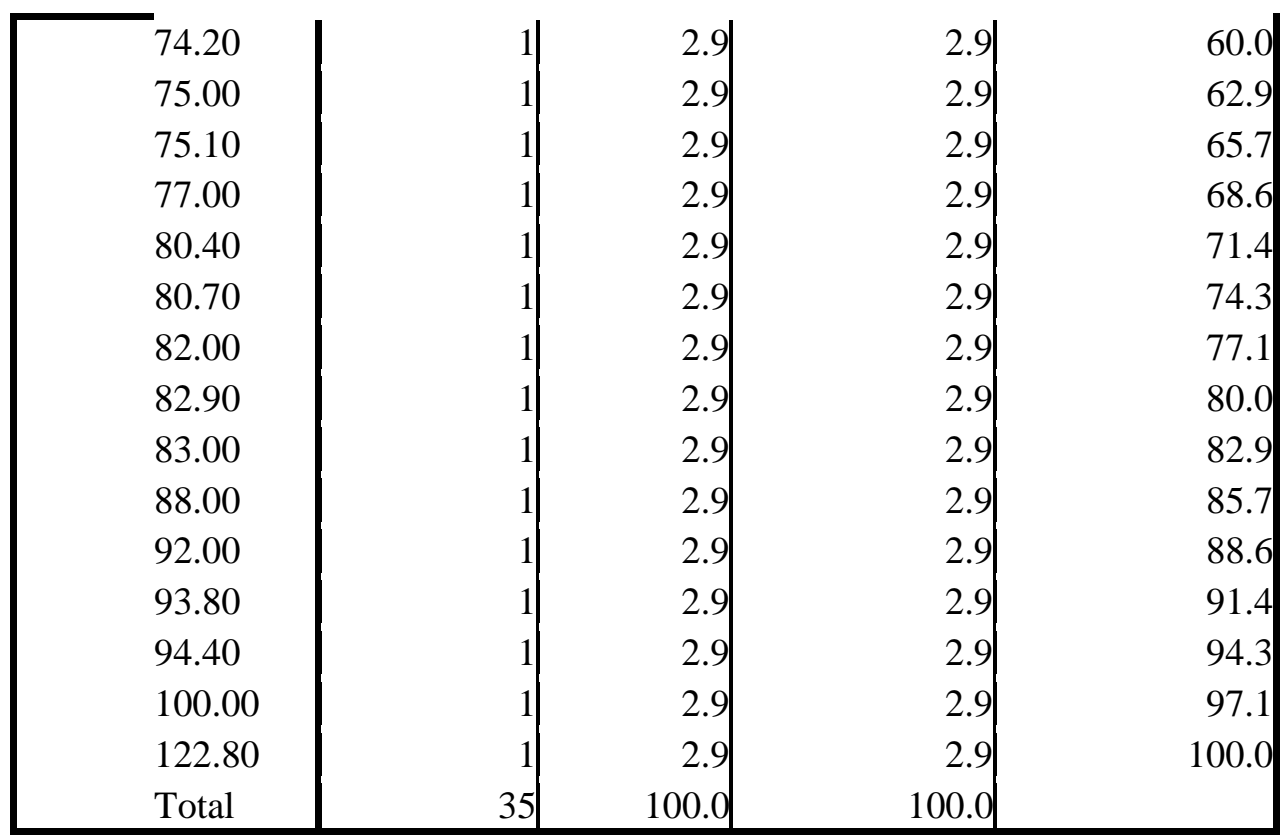

Descriptive Statistics

\begin{tabular}{|l|r|r|r|r|r|}
\hline & \multicolumn{1}{|c|}{ N } & Minimum & Maximum & Mean & Std. Deviation \\
\hline Weight & 35 & 52.40 & 122.80 & 75.1571 & 13.72701 \\
Valid N (listwise) & 35 & & & & \\
\hline
\end{tabular}

Table 6. Height

\begin{tabular}{|r|r|r|r|r|}
\hline & Frequency & Percent & Valid Percent & $\begin{array}{c}\text { Cumulative } \\
\text { Percent }\end{array}$ \\
\hline 1.43 & 1 & 2.9 & 2.9 & 2.9 \\
1.51 & 1 & 2.9 & 2.9 & 5.7 \\
1.52 & 1 & 2.9 & 2.9 & 8.6 \\
1.53 & 2 & 5.7 & 5.7 & 14.3 \\
1.54 & 1 & 2.9 & 2.9 & 17.1 \\
1.56 & 2 & 5.7 & 5.7 & 22.9 \\
1.57 & 2 & 5.7 & 5.7 & 28.6 \\
1.58 & 1 & 2.9 & 2.9 & 31.4 \\
1.59 & 1 & 2.9 & 2.9 & 34.3 \\
1.60 & 1 & 2.9 & 2.9 & 37.1 \\
1.61 & 1 & 2.9 & 2.9 & 40.0 \\
1.63 & 3 & 8.6 & 8.6 & 48.6 \\
1.64 & 3 & 8.6 & 8.6 & 57.1 \\
1.65 & 1 & 2.9 & 2.9 & 60.0 \\
1.66 & 1 & 2.9 & 2.9 & 62.9 \\
& & 26 & & \\
\hline
\end{tabular}




\begin{tabular}{|c|c|c|c|c|}
\hline 1.70 & 2 & 5.7 & 5.7 & 68.6 \\
\hline 1.72 & 1 & 2.9 & 2.9 & 71.4 \\
\hline 1.73 & 2 & 5.7 & 5.7 & 77.1 \\
\hline 1.75 & 2 & 5.7 & 5.7 & 82.9 \\
\hline 1.76 & 1 & 2.9 & 2.9 & 85.7 \\
\hline 1.77 & 2 & 5.7 & 5.7 & 91.4 \\
\hline 1.78 & 1 & 2.9 & 2.9 & 94.3 \\
\hline 1.79 & 1 & 2.9 & 2.9 & 97.1 \\
\hline 1.80 & 1 & 2.9 & 2.9 & 100.0 \\
\hline Total & 35 & 100.0 & 100.0 & \\
\hline
\end{tabular}

Descriptive Statistics

\begin{tabular}{|l|r|r|r|r|r|}
\hline & \multicolumn{1}{|c|}{$\mathrm{N}$} & Minimum & Maximum & Mean & Std. Deviation \\
\hline Height & 35 & 1.43 & 1.80 & 1.6449 & .09559 \\
Valid N (listwise) & 35 & & & & \\
\hline
\end{tabular}

Table 7. Body Mass Index of Respondents $(\mathbf{n}=35)$

BMI

\begin{tabular}{|r|r|r|r|r|}
\hline & Frequency & Percent & Valid Percent & $\begin{array}{c}\text { Cumulative } \\
\text { Percent }\end{array}$ \\
\hline 25.03 & 1 & 2.9 & 2.9 & 2.9 \\
25.09 & 1 & 2.9 & 2.9 & 5.7 \\
25.16 & 1 & 2.9 & 2.9 & 8.6 \\
25.22 & 1 & 2.9 & 2.9 & 11.4 \\
25.33 & 2 & 5.7 & 5.7 & 17.1 \\
25.36 & 1 & 2.9 & 2.9 & 20.0 \\
25.41 & 1 & 2.9 & 2.9 & 22.9 \\
25.46 & 1 & 2.9 & 2.9 & 25.7 \\
25.62 & 1 & 2.9 & 2.9 & 28.6 \\
25.63 & 1 & 2.9 & 2.9 & 31.4 \\
25.65 & 1 & 2.9 & 2.9 & 34.3 \\
25.70 & 1 & 2.9 & 2.9 & 37.1 \\
25.90 & 1 & 2.9 & 2.9 & 40.0 \\
26.09 & 1 & 2.9 & 2.9 & 42.9 \\
26.37 & 1 & 2.9 & 2.9 & 45.7 \\
26.40 & 1 & 2.9 & 2.9 & 48.6 \\
26.58 & 1 & 2.9 & 2.9 & 51.4 \\
27.07 & 1 & 2.9 & 2.9 & 54.3 \\
27.14 & 1 & 2.9 & 2.9 & 57.1 \\
& & 27 & & \\
\hline
\end{tabular}




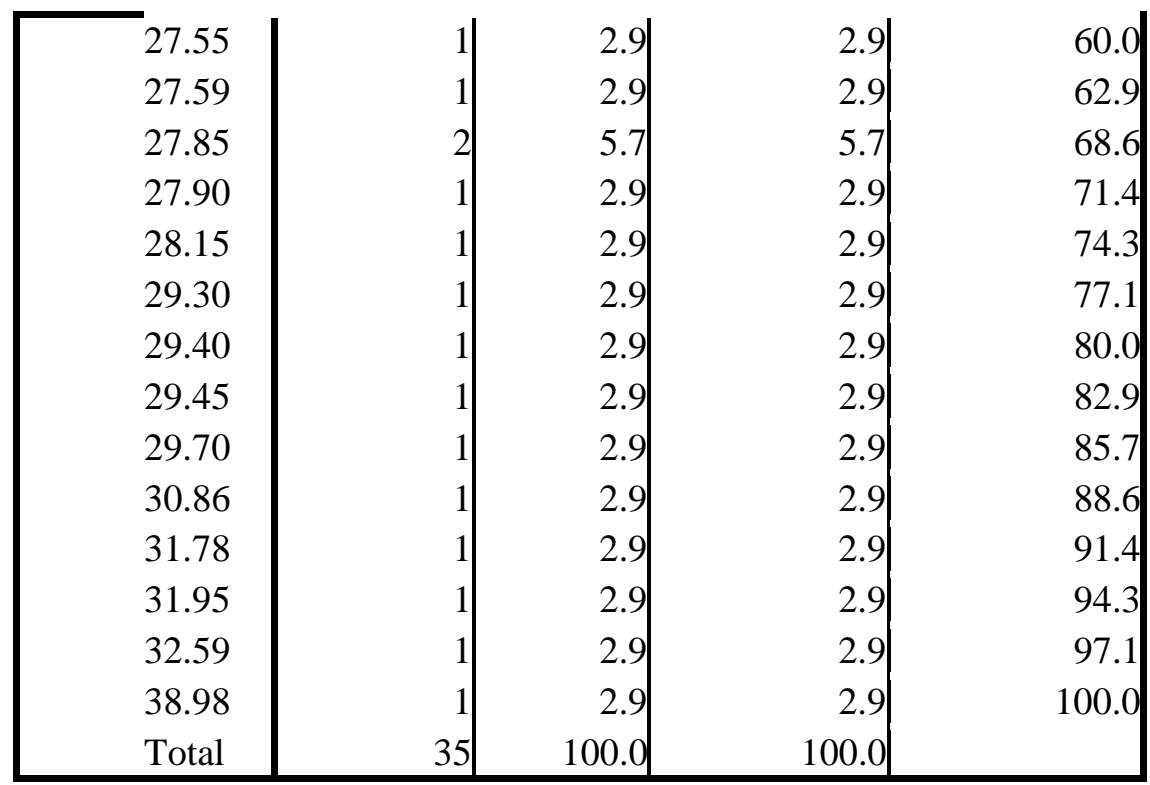

\section{Descriptive Statistics}

\begin{tabular}{|l|r|r|r|r|r|}
\hline & \multicolumn{1}{|c|}{ N } & Minimum & Maximum & Mean & Std. Deviation \\
\hline BMI & 35 & 25.03 & 38.98 & 27.6126 & 2.92049 \\
\hline Valid N (listwise) & 35 & & & & \\
\hline
\end{tabular}

\section{Data Analysis}

Based on the calculation the respondent's average BMI is $27.6126 \mathrm{~kg} / \mathrm{m}^{2}$. With this BMI figure, by looking at table 3.1, both male and female respondents belong to category 4 .

\section{Data Interpretation}

Based on table 1 category 4 is interpreted as Obese for both male and female respondents (> $27 \mathrm{~kg} / \mathrm{m}^{2}$ ). This is consistent with the explanation of Physical Maturity which is one of the characteristics of adolescents, is a maximum growth of height so quickly. This happens because in adolescence, a person receives a significantly increased food intake than when they are a child. As a result, adolescents receive excessive food intake leading to obesity.

Identification of the second problem: What is the child's perception of the body shape of parents at Singkawang Adventist School?

To answer the second formulation question, it is done by looking at the body shape of the parents according to the child's perception or view as overweight or obese. 
Table 8. Scale According to the Who of Male Body Shape

\begin{tabular}{lcl}
\hline INTERVAL & CATEGORY & INTERPRETATION \\
$<18 \mathrm{~kg} / \mathrm{m}^{2}$ & 1 & Underweight \\
$18-25 \mathrm{~kg} / \mathrm{m}^{2}$ & 2 & Normal \\
$25-27 \mathrm{~kg} / \mathrm{m}^{2}$ & 3 & Overweight \\
$>27 \mathrm{~kg} / \mathrm{m}^{2}$ & 4 & Obesity \\
\hline
\end{tabular}

Table 9. Scale According to the Who of Female Body Shape

\begin{tabular}{lcl}
\hline INTERVAL & CATEGORY & INTERPRETATION \\
$<17 \mathrm{~kg} / \mathrm{m}^{2}$ & 1 & Underweight \\
$17-23 \mathrm{~kg} / \mathrm{m}^{2}$ & 2 & Normal \\
$23-27 \mathrm{~kg} / \mathrm{m}^{2}$ & 3 & Overweight \\
$>27 \mathrm{~kg} / \mathrm{m}^{2}$ & 4 & Obesity \\
\hline
\end{tabular}

Table 10. Father's Body Shape

\begin{tabular}{|l|r|r|r|r|}
\hline & Frequency & Percent & Valid Percent & $\begin{array}{c}\text { Cumulative } \\
\text { Percent }\end{array}$ \\
\hline Underweight & 6 & 17.1 & 17.1 & 17.1 \\
Normal & 7 & 20.0 & 20.0 & 37.1 \\
Valid & 13 & 37.1 & 37.1 & 74.3 \\
Overweight & 9 & 25.7 & 25.7 & 100.0 \\
Obesity & 35 & 100.0 & 100.0 & \\
Total & & &
\end{tabular}

Descriptive Statistics

\begin{tabular}{|l|r|r|r|r|r|}
\hline & \multicolumn{1}{|c|}{ N } & Minimum & Maximum & Mean & Std. Deviation \\
\hline Father's Body & 35 & 1.00 & 4.00 & 2.7143 & 1.04520 \\
Shape & 35 & & & & \\
Valid N (listwise) & & & & & \\
\hline
\end{tabular}

Tabel 11. Mother's Body Shape

\begin{tabular}{|l|r|r|r|r|}
\hline & Frequency & Percent & Valid Percent & $\begin{array}{c}\text { Cumulative } \\
\text { Percent }\end{array}$ \\
\hline Underweight & 2 & 5.7 & 5.7 & 5.7 \\
Normal & 5 & 14.3 & 14.3 & 20.0 \\
Valid & 21 & 60.0 & 60.0 & 80.0 \\
Overweight & 7 & 20.0 & 20.0 & 100.0 \\
Obesity & 35 & 100.0 & 100.0 & \\
Total & \multicolumn{3}{|c}{} \\
\hline
\end{tabular}




\section{Descriptive Statistics}

\begin{tabular}{|l|r|r|r|r|r|}
\hline & \multicolumn{1}{|c|}{ N } & Minimum & Maximum & Mean & Std. Deviation \\
\hline Mother's Body & 35 & 1.00 & 4.00 & 2.9429 & .76477 \\
Shape & 35 & & & & \\
Valid N (listwise) & & & & & \\
\hline
\end{tabular}

\section{Data Analysis}

Based on the table above, the average body shape of the father is: 2.7143 when referred to table 3.2 , it is categorized close to 3. While the mother's body shape according to the child's perception is 2,9429 , which is the categorized as 3 .

\section{Data Interpretation}

Based on the data analysis above, the category 3 is referred to in table 3.2 . which is then interpreted as obese. Both father and mother are both interpreted as overweight according to the child's perception.

Formulation of the third problem: Is there a significant relationship between the profile of the body shape of parents with adolescents that are obese at Singkawang Adventist School?

Table 12. BMI Correlations between Adolescence and Father's Body Shape

\section{Correlations}

\begin{tabular}{|c|c|c|c|}
\hline & & BMI & $\begin{array}{c}\text { Father's Body } \\
\text { Shape }\end{array}$ \\
\hline \multirow{3}{*}{ IMT } & Pearson Correlation & 1 & .295 \\
\hline & Sig. (2-tailed) & & .086 \\
\hline & $\mathrm{N}$ & 35 & 35 \\
\hline \multirow{3}{*}{$\begin{array}{l}\text { Father's Body } \\
\text { Shape }\end{array}$} & Pearson Correlation & .295 & \\
\hline & Sig. (2-tailed) & .086 & \\
\hline & $\mathrm{N}$ & 35 & 35 \\
\hline
\end{tabular}

Tabel 13. BMI Correlations between Adolescence and Mother's Body Shape

\begin{tabular}{|c|c|c|c|}
\hline \multicolumn{4}{|c|}{ Correlations } \\
\hline & & BMI & $\begin{array}{l}\text { Mother's Body } \\
\text { Shape }\end{array}$ \\
\hline IMT & $\begin{array}{l}\text { Pearson Correlation } \\
\text { Sig. (2-tailed) }\end{array}$ & 1 & $\begin{array}{l}.143 \\
.411\end{array}$ \\
\hline
\end{tabular}




\begin{tabular}{|ll|r|r|}
\hline & $\mathrm{N}$ & 35 & 35 \\
Mother's Body & Pearson Correlation & .143 & 1 \\
Shape & Sig. (2-tailed) & .411 & \\
& $\mathrm{~N}$ & 35 & 35 \\
\hline
\end{tabular}

\section{Data Analysis}

Based on the Pearson correlation, with the determination of $\alpha<0.05$, it was found that there is no significant relationship between obesity in adolescents with the body shape of the father with a significance of $(0.086)$ with a $\rho$ value $>0.05$ as well as no significant relationship between obesity in adolescents with the body shape of their mothers, with a significance of (0.411) with $\rho$ value $>0.005$.

\section{Data Interpretation}

Based on the analysis of the data above, there is no significant relationship between adolescent obesity snd the body shape of the father and mother. It can be concluded that there is not enough evidence to state rejecting the Null Hypothesis. In contrast to this study, according to Juliantini (2012) the results of his research about the relationship of a history of obesity in parents with the incidence of obesity in elementary school children, that both parents who are obese increase the risk of obesity in children as much as 10.5 times compared to parents that are not obese.

\section{DISCUSSION}

\section{Conclusion}

From the results of this study it can be concluded that:

1. Overweight Singkawang Adventist School students are considered obese.

2. The body shape of the parents of students at Singkawang Adventist School is considered overweight.

3. There is no significant relationship between overweight students with the body shape of parents, both the body shape of the father and the body shape of the mother. There is not enough evidence to reject the null hypothesis.

\section{Suggestion}

After conducting this research, the authors provide the following suggestions: 
1. To Singkawang Adventist School students to maintain a healthy lifestyle and try to lose weight so that the Body Mass Index can be better.

2. To the researcher planning on doing a similar study, the author recommends conducting research with a larger number of samples by analyzing the students' obesity level and assessing the body shape of the parents based on the obesity of both parents and the obesity level of one parent.

\section{REFERENCES}

Depkes. (2009). Klasifikasi Remaja, Jakarta

Dewi, M. R. \& Sidhiartoko, I. G. L. (2013). Prevalence and Risk Factors of Overweight and Obesity in Adolescent, Paediatr Indonesia 2002;42:2006-11.

Hayati. (2009). Faktor yang Berhubungan dengan Konsumsi Fast Food Waralaba Modern dan Tradisional pada Remaja Siswa SMU Negeri di Jakarta Selatan. Skripsi Departemen Gizi Masyarakat dan Sumberdaya Keluarga, Fakultas Pertanian Institut Pertanian Bogor, Bogor.

Handayani Mega Seasty, Dwiriani Cesilia Meti dan Riyadi, Hadi, (2013), Hubungan komposisi tubuh dan status pada remaja putri di perkotaan dan perdesaan, Jurnal Gizi dan Pangan, 8(3): 181-186.

Juliantini Ni Putu Lia dan I Gusti Lanang Sidiartha (2012) Jurusan Pendidikan Dokter, Fakultas Kedokteran Universitas Udayana

Pareira, M. A., \& Ludwig, D. S. Dietary Fiber and Body Weight Regulation Observations and Mechanisms, Paediatr. (in North Am. 2001;59: 556-9).

Roesli. (2014). Faktor Determinan yang Mempengaruhi Kegagalan Pemberian ASI Ekslusif pada Bayi di Kelurahan Mulyorejo Surabaya (Skripsi), Universitas Airlangga, Surabaya.

Undang-undang Perkawinan, No.1 Tahun 1974 